\title{
Exploring the Effect of Leader Member Exchange (LMX) Level on Employees Psychological Contract Perceptions
}

\author{
Atılhan Naktiyok ${ }^{1}$, Mehmet Emirhan Kula ${ }^{2 *}$ \\ ${ }^{1}$ Ataturk University, Prof. Dr., Department of Business, Erzurum, Turkey \\ ${ }^{2}$ Mehmet E. Kula, PhD Candidate, Erzurum Technical University, Department of Business, Erzurum, Turkey
}

\begin{tabular}{|c|c|}
\hline \multirow[b]{2}{*}{ Keywords: } & ABSTRACT \\
\hline & \multirow{4}{*}{$\begin{array}{l}\text { Leader member exchange (LMX) theory emphasizes that leaders establish different } \\
\text { associations with each one of their followers through a system of exchanges and a } \\
\text { psychological contract is an employee's beliefs regarding the mutual obligations between } \\
\text { the employee and an employer. Within this study the impact of subordinates' leader } \\
\text { member exchange level on perceived psychological contract violation has been identified at } \\
\text { first and it has been found that subordinates' leader member exchange level negatively } \\
\text { effect on perceived psychological contract violation. Also it is seen when the demographic } \\
\text { variables are taken into account that there are significant relations between education level, } \\
\text { type of employment and age categories. }\end{array}$} \\
\hline $\begin{array}{l}\text { Leader Member } \\
\text { Exchange, Psychological } \\
\text { Contracts, Perceived } \\
\text { Psychological Contract } \\
\text { Violation }\end{array}$ & \\
\hline $\begin{array}{l}\text { Received } \\
\text { 09 November } 2017\end{array}$ & \\
\hline $\begin{array}{l}\text { Received in revised form } \\
14 \text { May } 2018\end{array}$ & \\
\hline $\begin{array}{l}\text { Accepted } \\
\text { 03 June } 2018\end{array}$ & \\
\hline $\begin{array}{l}\text { Correspondence: } \\
\text { emirhan.kula@erzurum.edu.tr }\end{array}$ & (C)AIMI Journals \\
\hline
\end{tabular}

There is an inclusive and increasing variety of theories to enlighten the idea and practice of leadership. Trait theories have given rise to leadership research in the early 1900s. Walter and Scheibe (2013) argued that effective leaders share a number of common personality characteristics or traits. In response to the early criticisms of the trait approach, leadership was recognized as a set of behaviors. The behavioral theory evaluated what successful leaders did

*This paper has been presented at the International Conference on Business and Economic Studies in Houston, on March 23-26, 2017. 
and acknowledged comprehensive patterns that specified different leadership styles. While trait and behavioral theories had been significantly missing the environment as a component of leadership, the contingency theory arrived with an idea that no single psychological profile or set of stable traits links to leadership. As closely related with contingency theory, leader member exchange (LMX) theory emphasizes that leaders establish different associations with each one of their followers through a system of exchanges (Avolio, Walumbwa \& Weber, 2009). LMX hypothesize the subordinate roles; therefore, the quality of the leader-member exchanges is divided into two basic categories: the in-group and the out-group. On the other hand, psychological contracts are beliefs that individuals hold regarding terms and conditions of the reciprocal exchange agreement between themselves and their employer. When an individual perceives that the contributions he or she makes obligate the organization to reciprocity (or vice versa), a psychological contract emerges (Rousseau, 1989). The present study examined the impact of subordinates LMX level on perceived psychological contract with the relevant hypothesis and unexplored relation between LMX and psychological contract.

\section{Overview of Leadership Theories}

The phenomenon of leadership embraces an individual's capability to impact others to help achieve organizational goals. Kouzes and Posner (2007) presented an extensive leadership definition apart from leader's traits, behaviors, circumstances even followers: "Leadership can happen anywhere, at any time. It can happen in a huge business or a small one. It can happen in the public, private or social sector. It can happen in any function (p. 8). Therefore, it has been an ongoing discussion over years and since its inception, the scope of leadership has been idealized, highlighting the beneficial effects of leaders on followers and organizations (Naseer, Raja, Syed, Donia, \& Darr, 2016). Looking back over the past 100 years, we cannot imagine a more opportune time for the field of leadership studies (Avolio, et. al, 2009). There is an inclusive and increasing variety of theories to clarify the idea and practice of leadership. Trait theories have given rise to modern leadership research in the early 1900s.

Another approach proposed to leadership studies related to behavioral perspective. One of the major empirical contributions from the behavioral school was the identification of two broad classes of leader behaviors, task-oriented and person-oriented behaviors which were identified by repeated factor analyses conducted by the Ohio State group and the Michigan group (House \& Aditya, 1997). These dimensions of leader behavior are positively linked to many valued organizational outcomes including subordinate performance, group and organizational performance, subordinate job attitudes, and turnover (DeChurch, Hiller, Murase, Doty, \& Salas, 2010).

The other approach was called contingency approach which attempts to match a particular leadership style or type to specific external circumstances. The general idea is that one type of leadership will be effective in one situation, but a different type of leadership will be effective in another situation (Sims Jr., Faraj, \& Yun, 2009). Leader-Member Exchange (LMX) approach to leadership, grounded in role theory, is also intuitively appealing and has a suggestive body of empirical support (Dienesch \& Liden, 1986). 


\section{Leader-Member Exchange (LMX) Theory}

Graen and Uhl-Bien (1995) have developed a new approach to the study of leadership in organizations and was originally named the Vertical Dyad Linkage (VDL) theory. More recently studied known as Leader-Member Exchange Theory, theoretically was based on the concept of a "developed" or "negotiated" role (Dienesch \& Liden, 1986). Graen (1976) stated that "Organizational members accomplish their works through roles" (p. 1201) which shows that the approach is based on the role theory.

The main focus in LMX theory is that leaders improve different exchange relationships with their followers, whereby the quality of the relationship modifies the impact on important leader and member outcomes (Avolio et al., 2009). Additionally, Dienesch and Liden (1986) mentioned that "it is based on the concept that role-development will inherently result in differentiated role definitions and, therefore, in varied leader-member exchanges" (p. 621). The quality of the relationship is revealed by the degree of mutual expectation, support, admiration, and responsibility. The model as it stands describes how effective leadership relationships develop between dyadic "partners" in and between organizations (Graen \& Uhl-Bien, 1995). Furthermore, their dependents causing an "in group" and an "out group" within the organization. According to DeChurch et al. (2010), in-group members are highly trusted, motivated performers whom the leader responds to with greater attention and consideration than the out-group members.

The degree of LMX quality is directly related to superiors' performance. As House and Aditya (1997) stated "if quality of LMX is high, as perceived by subordinates, and if the superior-subordinate perceptions are mutual, there is a strong likelihood that superiors will both like subordinates and rate their performance as high due to this liking, rather than due to the subordinates' actual performance" (p. 16). Out-group subordinates have a more transactional low-quality relationship. Importantly, the focus of LMX is on the effects of the quality of the relationship between the leader and follower on resulting organizational outcomes (Gerstner \& Day, 1997). Just precisely how the leader chooses who falls into each category is unclear, but there is evidence that leaders tend to choose in-group members because they have demographic, attitude and personality characteristics that are similar to the leader's or higher level of competence than out-group members (Robbins \& Judge, 2008). Finally, a cultural perspective has been presented based on Hofstede's studies which is mentioning in-group/outgroup distinctions and may also be more apparent in more collectivistic, high uncertainty, and power distant cultures (Hofstede, 1991).

\section{Psychological Contract}

Organizations are constantly changing, and their employees are expected to go along with and adapt quickly and successfully to the changes. A natural consequence of organizational changes is the transformation of the employment relationship (Nikolaou, Tomprou, \& Vakola, 2007). Contracts are fundamental in employment relationships, forming incentives and contributions to membership in an organization (Rousseau, 1989). In other words, contracts are promises and assurances made in exchange for some compensation and are enforced in law. A psychological contract is an employee's beliefs regarding the mutual obligations between the employee and an employer (Lambert, Edwards, \& Cable, 2003). The main idea is that when 
there is fit between psychological contract anticipated and psychological contract realized, individuals will experience positive outcomes. When there is misfit, they will experience negative outcomes, which can be moderated by job crafting (Dizdar, 2009).

Argyris (1960) primarily used the term "psychological work contract" to describe "an inherent understanding between employees and their foreman that arose as a result of a specific management style and discussed that the relationship could improve in a way that employees would exchange higher efficiency" (p. 86). The type of relationship that develops between employees and organizations is fundamental to organizational success and survival as well as employee well-being. This relationship also forms the foundation of many streams of organizational behavior research, including research into the psychological contract. The employee and organization held solid beliefs of each other and it was the expectancy of fulfilling those anticipations that driven both parties to remain in that relationship. In addition to this, some expectations are widely shared, others are more individualized and the specificity of expectations may range from highly specific to very general (Coyle-Shapiro \& Parzefall, 2008). The present research also focuses on the effects of subordinates' leader member exchange level on perceived psychological contract.

Literature on the psychological contract theory suggests that violations are inevitable within contractual relationships; therefore, a violation occurs when one party in a relationship perceives another party that failed to fulfil promised obligations (Malhotra, Sahadev, \& Purani, 2017). At this point, employees will begin to disregard the inducement with less or no reaction. Additionally, Peng, Wong and Song (2016) highlighted that psychological contract violation is comprised of negative emotions of anger and frustration, it will naturally activate employee reaction to release the induced uncomfortable experiences from such strong negative emotion (p. 817). In addition to this, according to O'Neill and Adya (2007) "organizations looking to capitalize on the knowledge resources of their employees must understand that employees are likely to have very different PC perceptions at various stages of employment" (p. 413).

Following hypotheses are

$\mathbf{H}_{1}$ : Subordinates leader member exchange level negatively affect perceived psychological contract violation.

$\mathbf{H}_{2}$ : Perceived psychological contract violation differs in terms of education level

$\mathbf{H}_{3}$ : Perceived psychological contract violation differs in terms of type of employment.

$\mathbf{H}_{4}$ : Perceived psychological contract violation differs in terms of age. 


\section{Research Model}

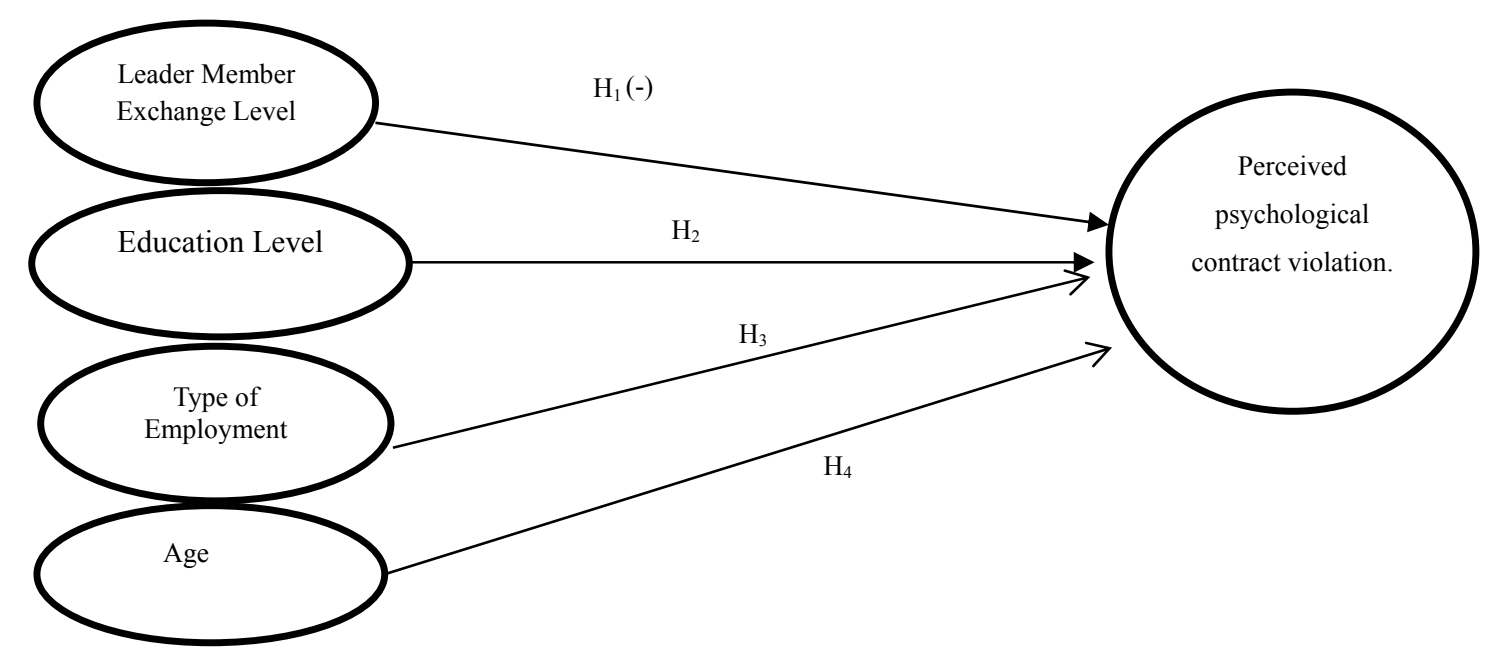

\section{Methods}

Through personal contacts, a questionnaire distributed at Erzurum Technical University's academic and administrative staff members to collect data. There were 276 academic and administrative staff members. The survey system web site (http://www.surveysystem.com/) was used to determine the sample size which was given 161. We have distributed 175 questionnaires and 163 questionnaires filled properly and collected back. The subordinate's level of leader member exchange has been asset with LMX-7 scale which was developed by Graen and Uhl-Bien (1995). Perceived psychological contract violation (PPCV) scale was used to collect data which developed by Robinson and Rousseau (1994). The 9-item scale was planned to measure the perceptions of those surveyed that their employers have fulfilled their obligations to them. For questions assess whether training and development, wages, promotion, nature of work, job security, feedback, change management, self-fulfillment opportunities, employees' expertise and co-work qualities were as promised. The scoring system required by the structure of the psychological contract violation scale differs from the scoring system of leader-member exchange survey. The scores of those who responded to the psychological contract violation questionnaire were inversely scored. Eventually, the obtained Cronbach's Alpha values of LMX scale was .85 and PPCV scale was .88 .

\section{Findings}

Based on the questionnaire, $68.5 \%$ of the participants were men and $31.5 \%$ of them were women. In addition, $32.7 \%$ of the participants were single and $67.3 \%$ were married, $30.9 \%$ were between the ages of 18-29, $56.8 \%$ were between the ages of 30-45 and $12.3 \%$ were over 45 years old. Also $6.8 \%$ of the participants worked for less than 1 year, $59.9 \%$ worked for $1-4$ years and $33.3 \%$ worked for more than 4 years. According to the Confirmatory Factor Analysis results, all the variables included in the study indicated respectable agreement with the confirmatory factor analysis. However, $3^{\text {rd }}$ question on LMX Survey and $3^{\text {rd }}$ and $9^{\text {th }}$ questions on PPCV were excluded due to reduced compliance on confirmatory factor analysis. When these questions were excluded, the variables became more acceptable with the reference 
values. Thus, LMX was measured by 6 items and PPCV by 7 items. Relevant compliance indices after the modifications are given in Table 1.

Table 1

Goodness of Fit Index Obtained from Confirmatory Factor Analysis

\begin{tabular}{lcccccccc}
\hline & $\chi^{2}$ & SD & $\chi^{2} /$ SD & CFI & NFI & NNFI & AGFI & RMSEA \\
\hline LMX & 9 & 20.88 & .431 & .98 & .97 & .97 & .90 & .071 \\
PC & 14 & 27.14 & .51 & .99 & .97 & .98 & .91 & .076 \\
\hline
\end{tabular}

The main statistical values and correlation coefficients for the variables included in the study are summarized in Table 2.

Table 2

Descriptive Statistics and Correlation Factors Related to Variables

\begin{tabular}{lcccc}
\hline Variables & $M$ & $S D$ & 1 & 2 \\
\hline 1-LMX & 3.64 & .80 & 1 & 1 \\
2-PC & 2.68 & .85 & $-628^{* *}$ & 1 \\
\hline
\end{tabular}

** Correlation is significant at the level of 0.01 .

* Correlation is significant at 0.05 level.

As shown in Table 2, there is a strong and significant negative relationship between LMX (leader-member exchange) and PPCV (perceived psychological contract violation). The hypothesis results on direct effects according to findings are summarized in Table 3:

Table 3

Hypothesis Results on Direct Effects

\begin{tabular}{|c|c|c|c|c|c|c|}
\hline Dependent Variable & \multicolumn{6}{|c|}{ Independent Variable } \\
\hline \multirow{3}{*}{ PPCV } & \multicolumn{6}{|l|}{ LMX } \\
\hline & $\beta$ & $t$ & $p$ & $\mathrm{R}^{2}$ & D. $R^{2}$ & $\mathrm{~F}$ \\
\hline & -.628 & -10.22 & $.001^{* *}$ & .39 & .39 & 10.45 \\
\hline
\end{tabular}

According to the results of the regression analysis, $39 \%$ of the total variance of psychological contract violations $\left(\mathrm{R}^{2}=.39\right)$ describes the leader-member interaction. It was observed that the level of subordinate's leader-member exchange level negatively and significantly influenced the individual's violation of psychological contract.

As presented in Table 3, the model has explanatory power. According to the correlation analysis and the regression analysis implemented, $\mathrm{H}_{1}$, "Subordinates leader member exchange level negatively affects perceived psychological contract violation", has been accepted.

Table 4

Comparison of Perceived Psychological Contract Violation with Participants' Education Levels

\begin{tabular}{|c|c|c|c|c|c|c|}
\hline & Education Level & $\begin{array}{l}\text { Education Level } \\
\text { Difference }\end{array}$ & Mean Difference & $\begin{array}{c}\text { Standard } \\
\text { Deviation }\end{array}$ & $F$ & $P$ \\
\hline $\begin{array}{l}\text { Perceived Psychological } \\
\text { Contract Violation }\end{array}$ & Undergraduate & $\begin{array}{c}\text { Secondary Education } \\
\text { High School } \\
\text { Graduate }\end{array}$ & $\begin{array}{c}.40 \\
.18 \\
-.40 *\end{array}$ & $\begin{array}{l}.27 \\
.33 \\
.13\end{array}$ & 2.34 & .05 \\
\hline
\end{tabular}

$*: \mathrm{p}<.05$ 
Regarding perceived psychological contract violations according to the level of participants' education, significant differences were only found between the undergraduate and graduate degrees. According to the results shown in Table 4, the psychological contract violation was significantly higher on undergraduate groups than the graduate groups. Therefore, hypothesis 2 is accepted.

Table 5

Comparison of Perceived Psychological Contract Violation with Participants' Type of Employment.

\begin{tabular}{|c|c|c|c|c|c|c|}
\hline & $\begin{array}{c}\text { Type of } \\
\text { Employment }\end{array}$ & $\begin{array}{l}\text { Type of Employment } \\
\text { Difference }\end{array}$ & $M$ & $S D$ & $F$ & $P$ \\
\hline $\begin{array}{l}\text { Perceived Psychological } \\
\text { Contract Violation }\end{array}$ & Academics & $\begin{array}{l}\text { Administrative } \\
\text { Contractual }\end{array}$ & $\begin{array}{l}.55^{* *} \\
.30\end{array}$ & $\begin{array}{l}.13 \\
.35\end{array}$ & 2.55 & .001 \\
\hline
\end{tabular}

Concerning perceived psychological contract violations according to the level of participants' type of employment, significant differences were only found between the academics and administrative employees. According to the results shown in Table 5, the psychological contract violation was significantly lower on academics than the administrative employees. For this reason, hypothesis 3 is accepted.

Table 6

Comparison of Perceived Psychological Contract Violation with Participants' Ages.

\begin{tabular}{lllllll}
\hline & Age & Age Difference & $M$ & $S D$ & $F$ & $P$ \\
\hline $\begin{array}{l}\text { Perceived Psychological } \\
\text { Contract Violation }\end{array}$ & $45+$ & Between 30-45 & $-.68^{* *}$ & .14 & 2.83 & .01 \\
\hline
\end{tabular}

Regarding perceived psychological contract violations according to the level of participants' ages, the significant differences were found between the age groups. According to the results shown in Table 6, the psychological contract violation on over 45 years old group was significantly higher than the other age groups. Therefore, hypothesis 4 is accepted.

Table 7

Hypothesis Test Results

\begin{tabular}{lcc}
\hline Model & Hypothesis & Results \\
\hline LMZ $\rightarrow$ PC & $\mathrm{H}_{1}$ & Accepted \\
EDU $\rightarrow$ PC & $\mathrm{H}_{2}$ & Accepted \\
DEP $\rightarrow$ PC & $\mathrm{H}_{3}$ & Accepted \\
AGE $\rightarrow$ PC & $\mathrm{H}_{4}$ & Accepted \\
\hline
\end{tabular}

As displays in Table 7, all hypotheses were accepted.

\section{Conclusion}

In this study, the subordinates' leader member exchange level had an effect on perceived psychological contract violation and the subordinates' leader member exchange level negatively had an effect on perceived psychological contract violation. In other words, a 
positive affect has been observed between subordinates LMX level and a positive relationship is observed between the levels of employee interaction with the leader and psychological contract perceptions. The most successful organizations are able to attract and maintain top capacity by entering into psychological contracts with their employees that motivate them to produce and share knowledge and experience in return for developing their professional skills (O’Neill \& Adya, 2007). Subordinates personal confidence on their supervisors and their perceptions on being an in-group member, basically strengthen the psychological ties with their organizations. It was observed that there were significant relations between education level, type of employment and age categories when the demographic variables were taken into account. Moreover, these demographic data support the first conclusion of the first hypothesis. In fact, the results related to type employment on hypothesis four indicated that perceived psychological contract violation on the academic staff was low and it was high on the administrative staff, that is, psychological contract commitment is high on academic staff members. A study on academic staff member's organizational commitment by Doğan and Demirel (2009) supported the consequences of our study, i.e., the organizational commitment had a positive impact on perceived psychological contracts. In this study, we only took subordinates opinions into consideration and the management level of the university did not involve in the assessment.

\section{References}

Argyris, C. (1960). Understanding organizational behavior. Homewood, IL: Dorsey Press.

Avolio, B. J., Walumbwa, F. O., \& Weber, T. J. (2009). Leadership: Current theories, research, and future directions. The Annual Review of Psychology, 49, 421-429

Coyle-Shapiro, A-M., \& Parzefall, M. (2008). Psychological contracts. In L. C. Cooper \& J. Barling. (Eds.), The SAGE handbook of organizational behavior (pp. 17-34). London, UK: SAGE Publications,

DeChurch, L. A., Hiller, N. J., Murase, T., Doty, D., \& Salas, E. (2010). Leadership across levels: Levels of leaders and their levels of impact. The Leadership Quarterly, 21, 1069-1085.

Dienesch. R. M, \& Liden, R. C. (1986), Leader-member exchange model of leadership: A critique and further development. The Academy of Management Review, 11, 618-634

Dizdar, Ö. A. (2009). Psychological contracts and organizational correlates: The impact of work orientations (Doctoral dissertation). Retrieved from Council of Higher Education Thesis Center (No.251004).

Doğan, S., \& Demiral, Ö. (2009). A study on the effect of personnel strengthening and psychological contract on organizational commitment. Erciyes University Economic and Administrative Sciences Faculty Journal, 32, 47-80.

Gerstner, C.R., \& Day, D.V. (1997). Meta-analytic review of leader-member exchange theory: Correlates and construct issues. Journal of Applied Psychology, 82, 827-844.

Graen, G. B. (1976). Role making processes within complex organization. In M. D. Dunnette, (Ed.), Handbook of industrial and organizational psychology (pp. 1201-1245.). Chicago, IL: Rand-McNally.

Graen, G. B., \& Uhl-Bien, M. (1995). Relationship-based approach to leadership: Development of leader-member exchange (LMX) theory of leadership over 25 years: Applying a multi-level multi-domain perspective. The leadership quarterly, 6(2), 219-247.

Hofstede, G. (1991). Cultures and organizations: Software of the mind. London: McGraw-Hill.

House, R. J., \& Aditaya, R. N. (1997). The social scientific study of leadership: Quo Vadis? Journal of Management, 23(3), 409-465.

Kouzes, J. M., \& Posner, B. J. (2007). Leadership challenge (4 ${ }^{\text {th }}$ ed.). San Francisco: Jossey-Bass.

Lambert, L. S., Edwards, J. R., \& Cable, D. M. (2003). Breach and fulfillment of the psychological contract: A comparison of traditional and expanded views. Personal Psychology. 56(4), 895-934. 
Malhotra, N., Sahadev, S., \& Purani, K. (2017). Psychological contract violation and customer intention to reuse online retailers: Exploring mediating and moderating mechanisms. Journal of Business Research, 75, 17-28.

Meydan, C. H., \& Şeşen, H. (2011). Yapısal eşitlik modellemesi: AMOS uygulamaları. Ankara: Detay Yayıncılık.

Naseer, S., Raja, U., Syed, F., Donia, M. B., \& Darr, W. (2016). Perils of being close to a bad leader in a bad environment: Exploring the combined effects of despotic leadership, leader member exchange, and perceived organizational politics on behaviors. The Leadership Quarterly, 27, 14-33.

Nikolaou, I., Tomprou, M., \& Vakola, M. (2007). Individuals' inducements and the role of personality: Implications for psychological contracts. Journal of Managerial Psychology, 22(7), 649-663.

O’Neill, B., \& Adya, M. (2007). Knowledge sharing and the psychological contract: Managing knowledge workers across different stages of employment. Journal of Managerial Psychology, 22(4), 411-436.

Peng, K. Z., Wong, C. S., \& Song, J. L. (2016). How do Chinese employees react to psychological contract violation? Journal of World Business, 51(5), 815-825.

Robbins, S. P., \& Judge, T. A. (2008). Organizational behavior (13th ed.). Prentice Hall.

Robinson, S.L., \& Rousseau, D. M. (1994). Violating the psychological contract: not the exception but the norm. Journal of Organizational Behavior, 15, 245-259

Rousseau, M. D., (1989). Psychological and implied contracts in organizations. Employee Responsibilities and Rights Journal, 2(2), 121-139

Sims, H. P., Jr., Faraj, S., \& Yun, S. (2009). When should a leader be directive or empowering? How to develop your own situational theory of leadership. Business Horizons, 52, 149-158.

Walter, F., \& Scheibe, S. (2003). A literature review and emotion-based model of age and leadership: New directions for the trait approach. The Leadership Quarterly, 24, 882-901. 